\title{
Care for the Acquired Immunodeficiency Syndrome in the contemporary world: understanding practitioners' view
}

\author{
O cuidado à Síndrome da Imunodeficiência Adquirida na contemporaneidade: \\ compreendendo o olhar de profissionais
}

Cleuma Sueli Santos Suto ${ }^{1}$, Mirian Santos Paiva ${ }^{1}$, Jeane Freitas de Oliveira ${ }^{1}$, Andreia Silva Rodrigues ${ }^{1}$, Daiane Santos Oliveira ${ }^{1}$, Carlos Alberto Porcino ${ }^{1}$

\begin{abstract}
Objective: to understand the perspective of health professionals on care for people with acquired immunodeficiency syndrome. Methods: this is a qualitative approach based on the Social Representation Theory based on the free speeches of 73 practitioners from four specialized public services, which were submitted to Factorial Correspondence Analysis. Results: practitioners with longer training and working time have emphasized aspects related to the syndrome such as physical degradation, abandonment and death; practitioners with shorter training and working time have represented the care of the person living with human immunodeficiency virus as an increased knowledge of sensitivity, indicating attitudes and behaviors socially constructed and accepted as belonging to health practitioners. Conclusion: practitioners with more experience have seen the syndrome in its negative and initial aspect; the newcomers to the professional practice have shown sensitivity and openness to the relevant issues of this phenomenon and concrete possibilities of more effective/transforming care practices.
\end{abstract}

Descriptors: Delivery of Health Care; HIV Infections; Acquired Immunodeficiency Syndrome; Health Personnel.

Objetivo: compreender o olhar de profissionais de saúde sobre cuidado a pessoas com síndrome da imunodeficiência adquirida. Métodos: abordagem qualitativa baseada na Teoria das Representações Sociais a partir de evocações livres de 73 profissionais, de quatro serviços públicos especializados, submetendo-as à Análise Fatorial de Correspondência. Resultados: os profissionais com maior tempo de formação e atuação enfatizaram aspectos relacionados à síndrome como degradação física, abandono e morte; os profissionais com menor tempo de formação e atuação representam o cuidado da pessoa vivendo com o vírus da imunodeficiência humana como um conhecimento acrescido de sensibilidade, indicando atitudes e comportamentos socialmente construídos e aceitos como próprios de profissionais de saúde. Conclusão: os profissionais com maior experiência veem à síndrome em seu aspecto negativo e inicial; os recém-chegados á prática profissional denotam sensibilidade e abertura para as questões relevantes deste fenômeno e, possibilidades concretas de práticas de cuidado mais efetivas/transformadoras.

Descritores: Assistência à Saúde; Infecções por HIV; Síndrome de Imunodeficiência Adquirida; Pessoal de Saúde.

\footnotetext{
${ }^{1}$ Universidade Federal da Bahia. Salvador, BA, Brazil. 


\section{Introduction}

At the end of the first decade of the 21st century, the epidemic of Acquired Immunodeficiency Syndrome (AIDS) has gained a new stage by giving visibility to a concentrated infection in certain vulnerable subgroups of population. At the beginning of the epidemic, there were predominant records among gay adults, people who used injectable drugs and hemophiliacs. Since the 1990s, there has been the reduction of these groups and a progressive increase, followed by the stability, of AIDS cases in the age group of 15 to 24 years, especially in the North and Northeast regions of Brazil ${ }^{(1)}$.

Other challenging aspects can be pointed out in the fight against the epidemic. Among them, there are the changes occurred in the sexual behaviors in our days. The increase in casual sex and the reduction in the use of condoms constitute an even more worrying scenario for health professionals regarding the management of sexually transmitted diseases among the sexually active population ${ }^{(2)}$. In this way, when experiencing situations of threat to their physical or emotional integrity, people usually feel fragile and sometimes are not able to cope with their conflicts alone, requiring, among other actions, support and/or assistance from the health practitioner.

Among the advances in the health demands of people living with Human Immunodeficiency Virus (HIV), the antiretroviral therapy has been decisive for AIDS to be configured as a chronic disease ${ }^{(3)}$. After this therapy has been instituted, the probability of illness, transmission of the virus and death has reduced considerably. In addition to drug therapy, the process of building a care model should have as its characteristics care as competence, professional updating and knowledge about the advances in the phenomenon of AIDS. In addition, the model needs to focus on the practitioner, the service user and the disease, based on technical/political/ethical competence ${ }^{(4)}$.

In this sense, care providers, among them the nurse, have to cope with moments of crisis and, to that end, face difficulties related to lack of time, precariousness in services, high amount of people receiving care and organizational management of care. These aspects reinforce in a daily basis the way of providing care to these people.

The possible visibility of the study object HIV/ AIDS through the interpretation of social discourses becomes possible with the contribution of Social Representation Theory. This theory is considered a fertile field for the studies addressing the health-disease process, besides evidencing the complexity of the relations between biological and social factors when exploring the relationship between official knowledge and common sense $\mathrm{e}^{(5)}$.

This study is justified by accessing the social representations of health practitioners, since it makes possible the (re) construction of the way of thinking and doing of individuals who participate directly in the assistance in specialized services. Therefore, considering that social representations emerge from current practices in society and culture ${ }^{(6)}$, the present article aimed to understand the perspective of health practitioners about care for people with acquired immunodeficiency syndrome.

\section{Methods}

This is a qualitative research based on the Social Representation Theory, which can be defined as a set of articulated concepts that originate in social practices and group diversities, whose functions are to give meaning to the social reality, to produce identities and to guide the conducts ${ }^{(7)}$.

Data collection took place in four specialized public services for being reference of care to people with HIV in the city of Salvador-Bahia. We used an instrument composed by the Free Speech Association technique with the inducing terms HIV/AIDS and Care for the person living with HIV/AIDS and sociodemographic data, contemplated by variables, namely age, 
working time in the unit, time since graduation, professional category and specific training in the area. Its application was individual, and participants were asked to evoke five words for each stimulus.

During the months of October and December 2015, of the 90 practitioners (physicians, nurses, social workers, therapists, pharmacists and psychologists) working in the institutions, who had more than a year since graduation and of working time in the service, 73 participated in the study, having been randomly selected.

The words evoked, after the process of lemmatization, were submitted to the factorial matching analysis, through the Tri-deux-Mots software. The software can be freely reproduced and performs the factorial analysis and a treatment of qualitative and quantitative data for the analysis of the sociological data $^{(8)}$.

The factorial correspondence analysis is a multivariate descriptive statistical technique that shows the affinities between certain rows and columns of a data matrix and is based on the hypothesis of the independence between the rows and the columns of this same table. The graphic resulting from the statistical analysis reveals the approximations and oppositions of the analyzed factors ${ }^{(9)}$.

The fixed variables were defined in the study design, namely professional category, time since graduation, years of professional activity and type of service. The opinion variables are composed of the elements evoked from the two inducing terms: HIV/AIDS and care of the person with HIV/AIDS. The factorial graphic was interpreted from the meaning presented in the contingency table provided by the software and contains the evocations and characteristics of the research participants, anchoring them in the Social Representations Theory and in the current literature.

The study complied with the formal requirements contained in the national and international regulatory standards for research involving human beings.

\section{Results}

The factorial analysis of correspondence made it possible to understand the daily reality of health practitioners, anchored in their social and cultural context. Thus, we sought to articulate the sociodemographic profile, its membership and interaction in the social group.

The profile of the participants stands out as to age, since $61.6 \%$ of the sample was in the age group between 35 and 55 years old and $90.4 \%$ of these individuals were female. Of the participants, $19.4 \%$ had between one and five years since graduation and $16.4 \%$ had a post-graduate degree. It is noteworthy that $41.4 \%$ had been working in the AIDS program for 6 to 15 years and $14.0 \%$ for more than 15 years.

The result of the association test applied to the 73 professionals verified that 676 words were evoked, of which 59 were different. The first factor (F1) explains $45.9 \%$ of the total inertia and has its own value of 0.07342 and the second (F2) explains $31.4 \%$ of the total inertia, with its own value of 0.045841 . The two factors together obtained $77.3 \%$ of significance, thus exceeding the minimum value expected in studies of social representations (15.0\%).

In the analysis of the graphic resulting from the data processed by the software, (F1), horizontal, explains the largest and most important portion of information on the data, being complemented by the information provided in (F2). By means of the software used they were placed in opposition to the fixed variables: time since graduation, working time, professional category and type of service. Each inducing stimulus was identified with a digit located at the end of the words, that is, number one for HIV/AIDS and number two for Caring for people with HIV/AIDS (Figure 1).

Data were processed using a frequency equal to or greater than four for evoking the same inducing stimulus, analyzed from the reading of the modalities - evocations distributed in an opposite way on the factors F1 and F2, and the factorial map determined by 
the most frequent and relevant responses to inducing stimuli. The analysis was based on the evoked words configured in the graphic in the two axes or opposite factors and that present a number corresponding to the stimulus.
Figure 1, the F1 it translates the most expressive words that were evoked by health practitioners. On the other hand, the (F2) reveals the words with lesser contribution and that, in the processing of the data by the software, presented themselves as the most relevant.

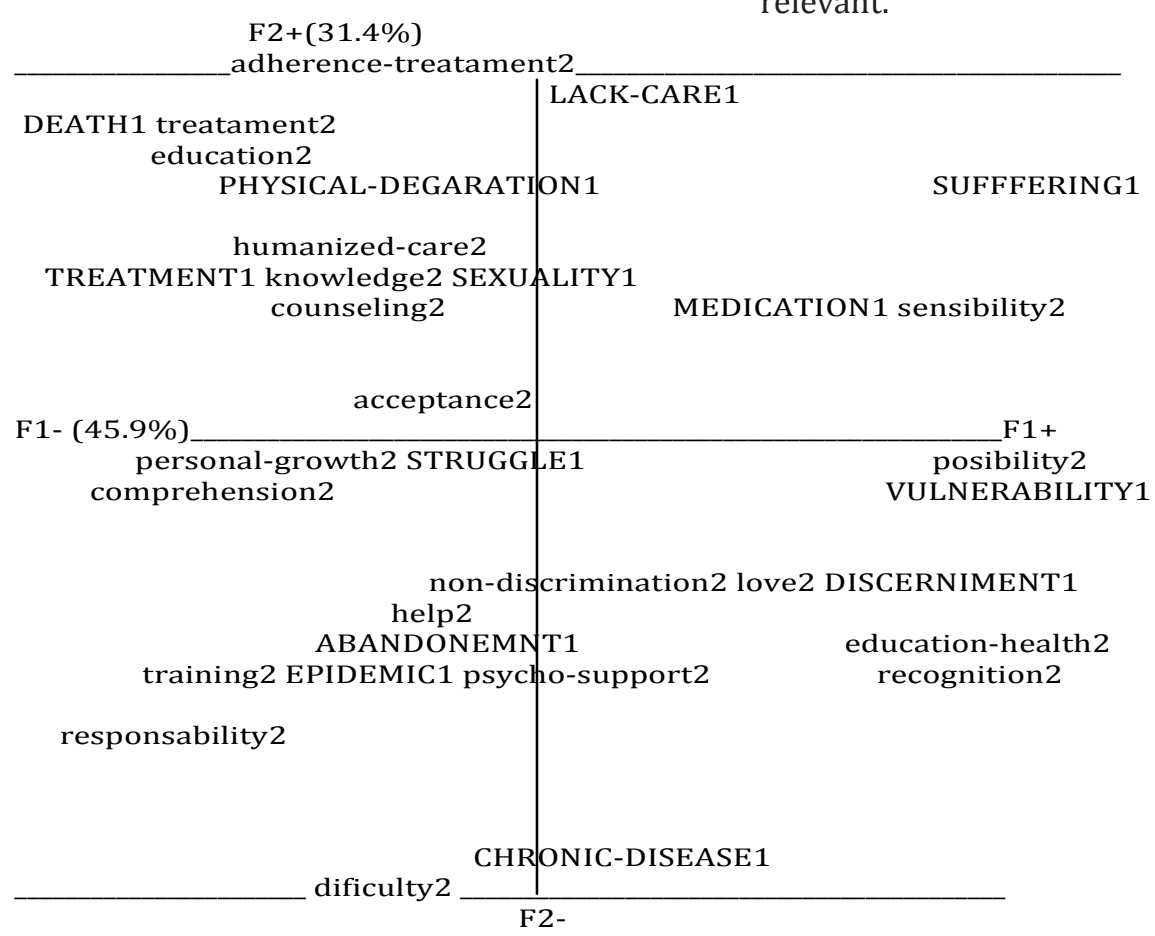

Figure 1 - Graphic of Factorial Correspondence Analysis of Social Representations of Practitioners on HIV/AIDS and Care of Individuals with HIV/AIDS, Tri-duex-Mots software

Factorial configuration: Factor 1, (F1) on the horizontal axis, left and right; Factor 2, (F2) on the upper and lower vertical axis
Contribution to each factor:
F1(+) Practitioners with working time of 1 to 9 years and time since graduation of 6 to 10 years
F1(-) ractitioners with more than 20 years of experience and more than 10 years since graduation
F2(+) Practitioners working in outpatient services
F2(-) Practitioners working in outpatient services and who have been working with HIV/AIDS for 10 to 20 years
Fixed variables: Profession; Time since graduation; Working time; Type of service
Opinion variables: 1-HIV/AIDS, in uppercase; 2-Caring for a person with HIV/AIDS

Figure 2 - Legend of Figure 1 
The F1 is considered the most important, since it concentrates the information of greater statistical value on the object studied (45.9\%). The graphic allowed identifying in this factor, on its left side (F1-), the semantic content of social representations elaborated by practitioners with more than twenty years of professional experience and practitioners with more than ten years since graduation. Stimulus 1 is represented by these groups as a disease characterized by physical degradation, abandonment, death and struggle. Representations related to caring for people with HIV/ AIDS for this group of practitioners are targeted at counseling, education, training, help, acceptance and humanized-care.

For this factor, practitioners with shorter working time (between 1-9 years) and time since graduation (between 6-10 years) also contributed, in its right side (F1+). For these practitioners, HIV/AIDS was represented by the terms 'suffering, discernment, vulnerability, sexuality and medication' and taking care of these people is objectified in 'knowledge, sensitivity, comprehension and possibilities'.

The F2, with a statistical value of $31.4 \%$, allowed us identifying in the upper part (F2+) the semantic content of the social representations of practitioners working in outpatient services linked to the hospital units, who had characterized AIDS through the terms lack of care, physical-degradation, suffering, treatment and death. Regarding care, the words treatment and adherence to treatment were evoked.

The (F2-) comprises the group formed by practitioners who develop their activities in specialized outpatient services and who have been working for ten to twenty years in direct care to people living with this disease. For these practitioners, HIV/AIDS was represented as an epidemic that leads to abandonment, requires discernment and is a chronic disease. However, they say that caring for people affected by this disease is translated into difficulty, since it requires responsibility, lacks training, help and recognition, and should promote psychological support, health education and treatment and it is an act/service that should be provided with love and without discrimination.

\section{Discussion}

Since it is a qualitative study based on the Social Representation Theory, the non-use of privileged and multiple techniques by this modality was a factor that limited the deepening of the discussion of the results. However, explaining the social representations of health practitioners about HIV/AIDS and care, based on latent aspects of cognition, characteristic of the technique of free association of words, allowed the procedural construction of the representation of this phenomenon.

Its applicability becomes unique inasmuch as it enables the evidence of phenomena related to the campaigns of the National Humanization Policy, currently disclosed in the network of health services of the Unified Health System and that may differ from the practice of the practitioners studied. Reflecting on care practices may contribute, to a certain extent, to the improvement of personnel management policies that respect the specificities, subjectivities and complexities of health practitioners working in specialized units in the context of this complex phenomenon of AIDS.

We have found in the semantic universe of social representation, in the (F1), terms that translate HIV/AIDS into the contemporary perspective aimed at treatment and at the same time terms that emphasize negative aspects related to HIV/AIDS, which are compatible with the onset of the epidemic and which refer to the beginnings of $\operatorname{AIDS}^{(4)}$. The stimulus Caring for people with HIV/AIDS is presented, regardless of the type of service, time of performance or time since graduation, as humanized and sensitive care.

Such terms call attention since these practitioners can be considered and/or characterized as the most experienced, or with greater ability in care practices. In this sense, the elaboration of social representations, being produced from the experiences of the participants in this group, can only be fully understood if they are analyzed together with their living conditions ${ }^{(10)}$. 
The representation of caring of people living with the virus or with clinical signs and symptoms of the disease was described, by practitioners with greater experience, in terms that indicate positive aspects and normative appreciation, such as counseling and understanding ${ }^{(8)}$. Humanized care based on counseling, present in the representation, is also related to the personal desire of these practitioners to offer care that contains the implication of the National Humanization Policy. It is worth emphasizing that, in order for the process of humanization of care to exist, it is necessary to raise means that culminate in the transformation of the process and of the working conditions of health practitioners.

Anchored in this perspective of changing the hegemonic model of care, a study on pedagogical strategies in professional training and practice revealed, after analyzing the challenges for the development of health promotion actions as a social practice, that this is attributed to the State as a trigger and the one that guarantees the right to health in the country ${ }^{(11)}$.

Practitioners with less performance time and time since graduation, (F1), represented HIV/AIDS by two important aspects, both in the understanding of the phenomenon and in its coping, by objectifying it in sexuality and medication. However, they also revealed negative aspects regarding the perception of the phenomenon in their daily practice.

The importance presented in a study carried out in Bolivia, when revealing that the prevention activities carried out in that country are not aware of the content and understanding of the sexualities of the main groups in which the epidemic is centered, thus contributing to an insufficient action ${ }^{(12)}$. For the Brazilian practitioners who participated in this research, the care for the person living with HIV was represented by sensitivity, showing to be associated with the attitudinal dimension of care ${ }^{(13)}$.

With respect to (F2), it is possible to establish an association considering the practitioners represented at the top of the graphic. The outpatient service practitioners, linked to hospital units, represented
AIDS in its most negative aspect - death. However, they emphasized the existence of treatment as a focus for care, so that such content may be a reflection of the work scenario of these practitioners ${ }^{(13-14)}$.

Practitioners with intermediate working time (10 to 20 years) and those working in specialized outpatient services are in direct opposition, by representing the syndrome as a chronic disease that requires discernment. This representational content may be directly related to the increasing demands faced by this professional group when taking care of the person with this disease, in view of the expansion of possibilities and forms of treatment, such as antiretroviral therapy ${ }^{(4,14)}$. Caring for these groups, despite the difficulties, can lead to professional recognition if it is carried out with love, based on investments in health education, denoting positive aspects and willingness to face the problem.

However, the working conditions offered are not always adequate to the development of the various activities necessary to meet the demands of people living with HIV, especially in public institutions ${ }^{(14)}$. These may also be the difficulties that practitioners working in specialized outpatient services were referring to.

The role of health practitioners in promoting adherence to antiretroviral therapy is essential, since they are facilitators in the follow-up and identification of factors related to the weaknesses and failures of adherence ${ }^{(15-16)}$. In the study of these authors, carried out in Recife, only one of the specialized outpatient services carries out activities with adherence groups. Such reality may also be found in other Northeastern capitals.

When studying the social representation of practitioners working in an emergency mobile unit in Rio de Janeiro, authors identified how the elements of suffering and death are classified in an imaginary dimension of the representation of care to the person at risk of life as a negative attribute ${ }^{(13)}$. Practitioners working in hospital-based units have outlined a similar representation, possibly because they unders- 
tand their performance as non-resolving, and admit the existence of human and technological barriers to care for the person living with HIV/AIDS, besides the patient's own suffering ${ }^{(16)}$.

Still in relation to (F2), although they are in direct opposition, practitioners with average time of performance and those who develop their activities in specialized outpatient services have clearly demonstrated the need for involvement of the caregiver with the being cared for, showing love and being responsible for them, and showing that caring for infected/sick people is an activity that requires responsibility and non-discrimination by the practitioners who work there.

\section{Conclusion}

The content of the social representations of health practitioners reflects figurative signs that are endorsed in scientific knowledge and in common knowledge, in open opposition. Factorial correspondence analysis portrays the view of participants with greater professional experience in specialized care, revealing that the initial and negative experiences of the epidemic, when they are carried to the present day, can be reflected in daily practices. With regard to practitioners with little professional practice or with less time since graduation, the presence of sensitivity and openness to the relevant issues of this phenomenon, such as sexuality and vulnerabilities, mean concrete possibilities of more effective and/or transformative care practices and in line with the National Humanization Policy.

\section{Collaborations}

Suto CSS, Paiva MS and Oliveira JF contributed to the conception, collection, organization, interpretation of data, writing and relevant critical analysis of intellectual content. Rodrigues AS, Oliveira DS and Porcino CA contributed to the writing of the article and final approval of the version to be published.

\section{References}

1. Ministério da Saúde (BR). Boletim epidemiológico - Aids e DST. Ano XIII - no 1 - 27a a 52a - semanas epidemiológicas - julho a dezembro de 2016. Brasília: Ministério da Saúde; 2016.

2. Streck VS. A feminilização do HIV/AIDS: Narrativas que interpelam as estruturas de poder na sociedade e igreja. Estud Teol [Internet]. 2012 [citado 2017 jun. 13]; 52(2):345-56. Disponível em: http://periodicos.est.edu.br/index.php/estudos_teologicos/article/view/305/401

3. Dourado I, MacCarthy S, Reddy M, Calazans G, Gruskin S. Revisiting the use of condoms in Brazil. Rev Bras Epidemiol. 2015; 18(Suppl 1):63-88. doi: http://dx.doi.org/10.1590/18094503201500050006

4. Koerich C, Santos FC, Meirelles BHS, Erdmann AL. Management of nursing care of the adolescent living with HIV/AIDS. Esc Anna Nery. 2015; 19(1):115-23. doi: http://dx.doi. org/10.5935/1414-8145.20150016

5. Spink MJ. Desenvolvendo as teorias implícitas: uma metodologia de análise das representações sociais. In: Guareschi PA, Jovchelovitch S, organizadores. Textos em representações sociais. Petrópolis: Vozes; 2013. p.117-45.

6. Sá CP. Teoria e pesquisa do núcleo central das representações sociais. In: Sá CP, organizador. Estudos de psicologia social: história, comportamento, representações e memória. Rio de Janeiro: EdUERJ; 2015. p.209-26.

7. Moscovici S. Representações Sociais: investigações em psicologia social. Petrópolis: Vozes; 2012.

8. Araújo LS, Coutinho MPL, Miranda RS, Saraiva ERA. Universo consensual de adolescentes acerca da violência escolar. Psico-USF. 2012; 17(2):24351. doi: http://dx.doi.org/10.1590/S141382712012000200008

9. Souza AXA, Nóbrega SM, Coutinho MPL. Representações sociais de adolescentes grávidas sobre a gravidez na adolescência. Psicol Soc. 2012; 24(3):588-96. doi: http://dx.doi.org/10.1590/ S0102-71822012000300012

10. JesuínoJC, Mende,FRP,Lopes MJ.Asrepresentações sociais nas sociedades em mudança. Petrópolis: Vozes; 2015. 
11. Netto L, Silva KL, Rua MS. Competency building for health promotion and change in the care model. Texto Contexto Enferm. 2016; 25(2):e2150015. doi:http://dx.doi.org/10.1590/010407072016002150015

12. Hita SR. Problemas metodológicos em las investigaciones sobre VIH/SIDA em Bolívia. Ciênc Saúde Coletiva. 2013; 18(5):1321-29. doi: http://dx.doi. org/10.1590/S1413-81232013000500017

13. Nascimento KC, Gomes AMT, Erdmann AL. Representational structure of intensive care for professionals working in mobile intensive care units. Rev Esc Enferm USP. 2013; 47(1):17684. doi: http://dx.doi.org/10.1590/S008062342013000100022

14. Costa TL, Oliveira DC, Formozo GA, Gomes AMT. Persons living with AIDS in nurses' social representations: analysis of central, contranormative and attitudinal elements. Rev Latino-Am Enfermagem. 2012; 20(6):1091-9. doi: http://dx.doi. org/10.1590/S0104-11692012000600011.
15. Abrão FMS, Angelima RCM, Cardosos MD, Queiroz SBA, Freitas RMM, Oliveira DC. Características estruturais e organizacionais de serviços de assistência especializada em HIV/aids na cidade de Recife, Brasil. Rev Baiana Saúde Pública [Internet]. 2014 -citado 2017 jun. 13]; 38(1):14054. Disponível em: http://rbsp.sesab.ba.gov.br/ index.php/rbsp/article/view/702/1161

16. Picelli I, Díaz-Bermúdez XP. Will these drugs be worthwhile? An anthropological study of adherence to antiretroviral therapies among support groups for people living with HIV and AIDS. Saúde Soc. 2014; 23(2):496-509. doi: http://dx.doi. org/10.1590/S0104-12902014000200011 